\title{
Memory B cell and antibody responses to flavivirus infection and vaccination
}

\author{
Awadalkareem Adam ${ }^{1}$ Servando Cuellar ${ }^{2}$ Tian Wang ${ }^{1,3,4^{*}}$ \\ ${ }^{1}$ Department of Microbiology \& Immunology, University of Texas Medical Branch, Galveston, TX, 77555, USA \\ ${ }^{2}$ School of Medicine, University of Texas Medical Branch, Galveston, TX, 77555, USA \\ ${ }^{3}$ Department of Pathology, University of Texas Medical Branch, Galveston, TX, 77555, USA \\ ${ }^{4}$ Sealy Institute for Vaccine Sciences, University of Texas Medical Branch, Galveston, TX, 77555, USA
}

\begin{abstract}
Flaviviruses are a group of mosquito- or tick-borne single-stranded RNA viruses that can cause a wide range of clinical manifestations in humans and animals, including asymptomatic, flu-like febrile illness, hemorrhagic fever, encephalitis, birth defects, and death. Many of them have no licensed vaccines available for human use. Memory B cell development and induction of neutralizing antibody responses, which are important for the control of flavivirus infection and dissemination, have been used as biomarkers for vaccine efficacy. In this review, we will discuss recent findings on memory B cells and antibody responses from studies in clinical specimen and animal models of flavivirus infection and vaccination with a focus on several clinically important flaviviruses, including dengue, West Nile, yellow fever, and Zika viruses.
\end{abstract}

\section{Peer Review}

The peer reviewers who approve this article are:

1. Penghua Wang, Department of Immunology, School of Medicine, The University of Connecticut Health Center, Farmington, Connecticut, USA

Competing interests: No competing interests were disclosed.

2. Kalpit A Vora, Department of Infectious Diseases and Vaccines Research, Merck \& Co., Inc, West Point, PA, USA Competing interests: Kalpit Vora currently works for Merck, Sharp \& Dohme; which is developing a Dengue vaccine. 
*Corresponding author: Tian Wang (ti1wang@utmb.edu)

Competing interests: The authors declare that they have no competing interests.

Grant information: This work was supported in part by NIH grant R01AI127744 (Tian Wang) and a grant from Sealy Institute for Vaccine Sciences at UTMB (Tian Wang).

The funders had no role in study design, data collection and analysis, decision to publish, or preparation of the manuscript.

Copyright: $\left({ }_{0} 2021\right.$ Wang T et al. This is an open access article distributed under the terms of the Creative Commons Attribution License, which permits unrestricted use, distribution, and reproductison in any medium, provided the original work is properly cited.

How to cite this article: Adam A, Cuellar S and Wang T. Memory B cell and antibody responses to flavivirus infection and vaccination. Faculty Reviews 2021 10:(5) https://doi.org/10.12703/r/10-5

Published: 25 Jan 2021, Faculty Reviews 10:(5) https://doi.org/10.12703/r/10-5 


\section{Introduction}

Flaviviruses are a group of single-stranded RNA viruses that are primarily transmitted by ticks or mosquitoes. Among them, there are several medically important human pathogens, such as dengue virus (DENV), yellow fever virus (YFV), West Nile virus (WNV), and Zika virus (ZIKV) $)^{1,2}$. Flaviviruses cause a wide range of clinical manifestations in humans and animals ranging from asymptomatic, self-limiting flu-like febrile illness to hemorrhagic fever, encephalitis, birth defects, and death ${ }^{2}$. No antiviral therapeutics are currently available. The flaviviral genome encodes three structural proteins (capsid, pre-membrane $[\operatorname{PrM}]$, and envelope $[\mathrm{E}]$ ) and seven nonstructural proteins (NS1, NS2A, NS2B, NS3, NS4A, NS4B, and NS5) ${ }^{3-5}$. The $\mathrm{E}$ protein has been reported to be involved in viral entry into host cells and is, thus, an important target for the induction of $\mathrm{B}$ cell and neutralizing antibodies (NAbs) ${ }^{6}$. The protein can be further divided into three domains: EDI, EDII, and EDIII. In addition, the NS1 and PrM proteins can serve as dominant targets for the human B cell response against flaviviruses ${ }^{7-9}$.

Vaccine development has been successful in the control of several flaviviruses, such as Japanese encephalitis virus (JEV), tick-borne encephalitis virus (TBEV), and YFV. Humoral immunity, which comprises B cell and antibody responses, plays an important role in host protection against flavivirus infection $^{10,11}$. In particular, the development of memory $\mathrm{B}$ cells (MBCs) and induction of NAb responses are critical for the control of viral infection and dissemination and, thus, are important biomarkers for vaccine efficacy ${ }^{12}$. Here, we mainly focus on discussion of recent progress in understanding the role of $\mathrm{MBCs}$ and antibody responses against flavivirus infection and vaccination.

\section{Memory B cells}

B cells are lymphocytes generated in the bone marrow from lymphoid precursors via a process involving the recombination of $\mathrm{V}, \mathrm{D}$, and $\mathrm{J}$ gene segments coding for the variable region of the immunoglobulin (Ig) heavy and light chains ${ }^{13}$. Mature naïve B cells express B cell receptor (BCR) such as IgM and $\mathrm{IgD}$ molecules. Following viral infection or vaccination, antigen stimulation of $\mathrm{B}$ cells through the BCR triggers the activation of naïve $B$ cells within a few days at the $T$ cell-B cell follicle border to eventually form follicular germinal centers (GCs), which generate long-lived plasma cells (LLPCs) producing IgG NAbs and antigen-specific MBCs within 7 days ${ }^{14,15}$. In extrafollicular foci, antigen-activated $B$ cells can differentiate into short-lived antibody secreting cells (ASCs) ${ }^{16,17}$. MBCs generated in the GC during the primary immune response circulate at low frequencies throughout the body as resting lymphocytes, which may persist for decades ${ }^{18}$. Upon antigen re-exposure, MBCs are activated, proliferate quickly (within 2 to 3 days) and more robustly than naive B cells, and differentiate into high-affinity $\operatorname{IgG~} \mathrm{ASCs}^{13,18}$. This activation also generates new antigen-specific LLPCs and MBCs. During primary flaviviral infection, there is a rapid and transient increase in antibody-secreting plasmablasts. At the convalescent stage, MBCs and LLPCs both contribute to long-term humoral immunity. Upon secondary flavivirus infection, MBCs are mostly characterized as highly cross-reactive to other genetically related flaviviruses.

\section{MBC and antibody responses to flavivirus infection and vaccination \\ DENV}

DENV infection is the most prevalent flavivirus infection, with about 390 million human cases annually in the tropical and subtropical regions worldwide ${ }^{19}$. The WHO has estimated that $50 \%$ of the world's population is at risk of DENV transmission. Based on antigenic determinants or nucleotide sequences of DENV E, Pre-M, or NS1 protein, there are four serotypes of DENV, namely DENV1, DENV2, DENV3, and DENV4 ${ }^{20}$.

Following a cutaneous DENV infection in immunocompetent mice (mimicking a mosquito bite), there was massive early activation and strong proliferation of B cells, but poor or almost absent $\mathrm{T}$ cell responses, which suggest a major role for humoral immunity during DENV infection ${ }^{21}$. One early study showed that the cross-reactive antibodies produced by both LLPCs and MBCs provided cross protection against sequential heterotypic DENV infection in AG129 mice (IFN- $\alpha / \beta$ and IFN- $\gamma$ receptor deficient). Nevertheless, most of the MBC studies to date have been conducted in human samples because of the limitation of physiologically relevant DENV infection animal models ${ }^{22}$. The predominant $\mathrm{B}$ cell responses during acute primary infection in humans are the CD27- and CD38-expressing DENV-specific plasmablasts, which produce DENV serotype-specific antibodies that mainly target the quaternary structure epitopes centered on DENV EDIII. The secretion of soluble CD27 and CD38 in the plasma was reported to be associated with the activation of the plasmablast during acute DENV infection ${ }^{23}$. B cells specific for DENV E, Pre-M, and NS1 were detectable in patients with primary DENV infection. In particular, DENV E-specific B cells had the highest frequencies and were highly serotype specific. However, during secondary DENV infection, DENV E-specific B cells were mostly serotype cross-reactive, which produced high-avidity antibodies ${ }^{23,24}$ (Figure 1A). Analysis of the diversity and antigen specificity of the plasmablast antibody repertoire elicited during primary DENV infections revealed that a high proportion of the DENV-elicited plasmablasts express $\operatorname{IgA}$, in addition to IgG and IgM class-switched cells. Furthermore, these IgA class-switched cells were extensively hypermutated ${ }^{25}$. Upon secondary DENV infection, small subsets of MBCs become activated as plasmablasts ${ }^{26}$. Single-cell analysis of B cells suggests that similar MBC responses were induced during primary and secondary DENV infection. However, during secondary infection, MBC responses were more cross-reactivated to other closely related flaviviruses, such as ZIKV ${ }^{27}$. The E-specific B cells in patients were serotype cross-reactive and secreted antibodies with higher avidity to heterologous DENV serotypes during secondary infection ${ }^{24,28,29}$. Characterization of serum samples from the secondary DENV infection reveals cross-reactive antibodies to all DENV serotypes (Figure $1 \mathrm{~B})^{30}$. Furthermore, plasmablast-derived monoclonal antibodies (mAbs) 


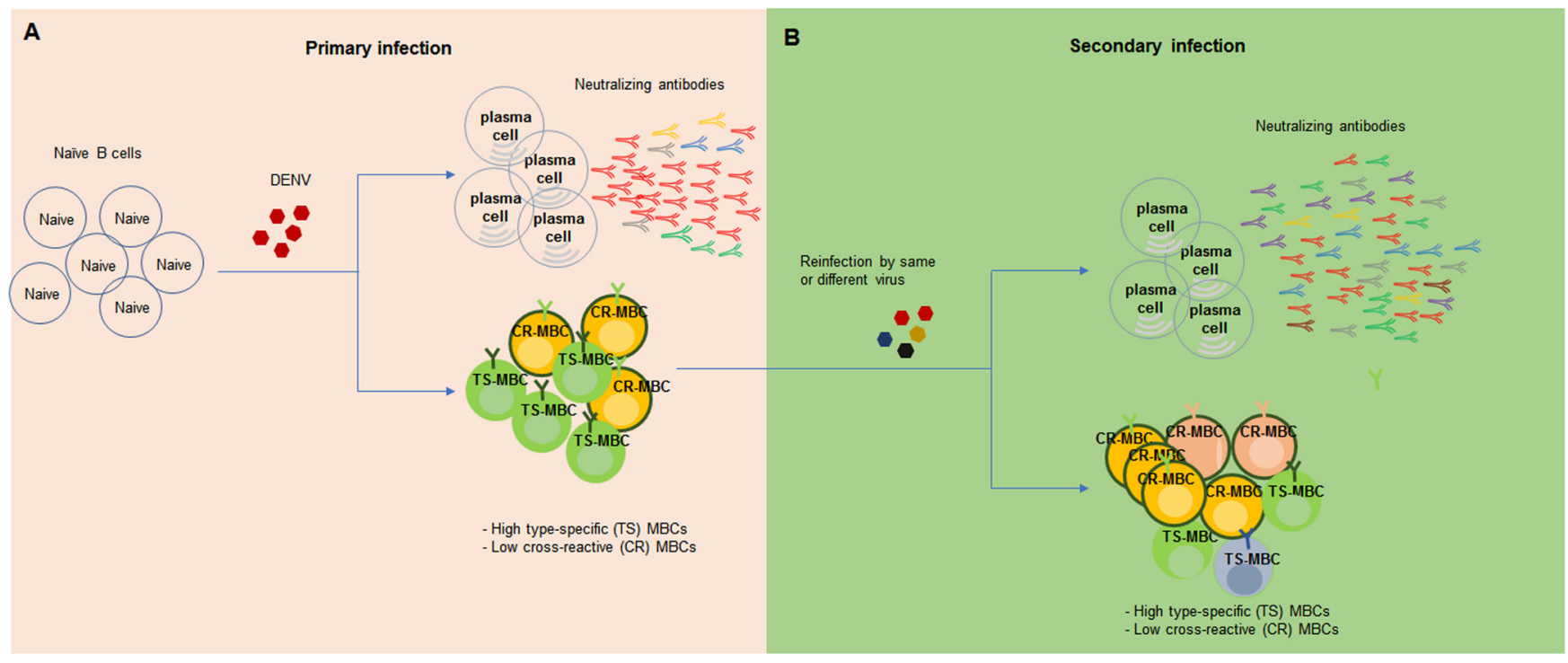

Figure 1. B cell responses following primary and secondary dengue virus (DENV) infections. A: During primary DENV infection, virusspecific naïve B cells are activated and differentiate into antibody-secreting long-lived plasma cells (LLPCs) and memory B cells (MBCs). B: During secondary infection with a different serotype DENV, MBCs are activated, produce cross-reactive antibodies with high avidity, and are expanded. New cross-reactive MBCs and LLPCs are also generated.

in DENV exposure donors were broadly cross-reactive against DENV 1-4, displayed poorly neutralizing activity, and showed antibody-dependent enhancement (ADE) effects in vitro ${ }^{31}$

Screening of samples from a DENV-endemic area suggested that more than $80 \%$ of subjects developed $\mathrm{MBCs}$ but the frequencies of these cells varied significantly ${ }^{32}$. The cross-reactive MBCs expanded during the first years of DENV infection and were retained in some donors for 3 to 4 years after initial infection. The antigenic specificity towards DENV serotypes or more distantly related flaviviruses, including ZIKV, also varied. Some donors had strong $\mathrm{MBC}$ responses to all four DENV serotypes that persisted for up to 5 years $^{33}$. In addition, MBC-derived antibodies were shown to bind to E, PrM, and NS1, which is more in line with the specificity of serum antibodies produced following re-infection and during the early convalescence phase ${ }^{26}$. Despite their low frequency in peripheral blood, human mAbs derived from purified MBCs have been characterized by several groups $^{34-36}$. For example, mapping of human MBCs and serum NAb responses to DENV serotype 4 infection and vaccination revealed that antibodies derived from MBCs and LLPCs bind to the quaternary structure epitopes close to the hinge region between EDI and $\mathrm{EDII}^{34}$. Young et al. generated $15 \mathrm{DENV} 3$ type-specific mAbs from $\mathrm{MBCs}$ isolated from children naturally infected with DENV and demonstrated that these antibodies recognize E glycoprotein ${ }^{37}$. Multiple approaches have also been developed for the assessment of the breadth and the durability of DENV/ZIKV B cell responses at the single-cell level following natural infection or vaccination. One group utilized the Alexa Fluor dye-labeled DENV to identify a small frequency of B cells from DENV immune individuals by flow cytometry analysis $^{38}$. Others developed DENV/ZIKV FluoroSpot assays for the detection and enumeration of DENV-specific, ZIKV-specific, and DENV/ZIKV cross-reactive $\mathrm{MBCs}^{39,40}$. These assays are sensitive tools to detect the specific and cross-reactive MBCs.

The generation of broadly NAbs (bNAbs) by B cells against all four DENV serotypes is crucial for DENV vaccine development. Durham et al. previously used transcriptomic analysis and identified novel recognition determinants of bNAbs within the DENV EDI region ${ }^{41}$.

Vaccination with TAK-003, a live attenuated tetravalent DENV vaccine candidate, which includes both attenuated DENV2 and three chimeric viruses containing the PrM/E of DENV1, 3, and 4 on the DENV2 backbone, induces both type-specific and cross-reactive MBCs to all four DENV serotypes. Thus, unlike natural DENV infection, all four components of TAK-003 contribute to the DENV-specific MBC response following vaccination.

\section{WNV}

WNV infection in humans induces West Nile fever and neuroinvasive diseases, including meningitis, encephalitis, acute flaccid paralysis, and death ${ }^{42}$. In addition, WNV convalescent patients developed long-term neurological sequelae or chronic kidney diseases, or both ${ }^{43-51}$.

Mature B cells play an important role in host protection against WNV infection. Mice with genetic deficiency in B cells and antibody were much more susceptible to lethal WNV infection ${ }^{10}$. Furthermore, evidence suggests that immature B cells also provide host protection against WNV infection. For 
example, immunization of $\mathrm{B}$ cell-activating factor receptor $(\text { BAFFR })^{-1-}$ mice, which have normal levels of immature B cells but reduced numbers of mature $\mathrm{B}$ cells, protects against lethal WNV infection ${ }^{52}$.

The persistence of WNV-specific MBCs and ASCs in WNV convalescent patients was first reported by Tsioris et al. ${ }^{53}$. In addition, they identified four novel WNV NAbs using the single-cell analysis method and NGS analysis. Vaccination of mice with the inactivated cell culture JEV antigen in the presence of Advax delta inulin adjuvant (JE-ADVAX) also triggered $\mathrm{MBC}$ responses and serum cross-NAb production, which together provided heterologous protection against WNV challenge $^{54}$. Furthermore, while both MBCs and LLPCs persist long after WNV clearance, depletion and adoptive transfer studies demonstrate that MBCs can respond to variant viruses that escape NAb produced by LLPCs without acquiring additional somatic mutations. In contrast, LLPC function was limited to neutralizing homologous viruses upon reinfection ${ }^{55}$.

The underlying mechanisms of MBC development during WNV infection are not well understood. It was reported that the expression of myeloid differentiation primary response 88 (MyD88) is required for B cell activation, development of GCs, and generation of LLPCs and MBCs following immunization with RepliVAX WN, a single-cycle flavivirus vaccine candidate derived from WNV. In contrast, the expression of Toll-like receptor (TLR) 3, which is independent of MyD88, is important for the maintenance of GCs and development of LLPCs but not for the differentiation of $\mathrm{MBCs}^{56}$. Thus, pathogen recognition receptor (PRR)-mediated innate immune signaling pathways could play differential roles in MBC and antibody responses upon WNV vaccination.

\section{YFV}

Yellow fever caused by YFV is endemic in South America and Africa. It is characterized by fever, vomiting, nausea, hepatitis with jaundice, renal failure, hemorrhage, and death ${ }^{57}$. YFV 17D is a highly live attenuated vaccine that was developed by Max Theiler in the 1930s. The three 17D substrains (17D-204, 17DD, and 17D-213) have minor differences in genome sequences, but all have proved to be effective vaccines ${ }^{58}$.

Mouse model studies suggest that the vaccine induces long-lasting humoral responses and provides protection along with memory $\mathrm{CD}^{+} \mathrm{T}$ cell immunity ${ }^{59}$. Wec et al. recently characterized MBC responses following YFV17D vaccination by using a high-throughput single B cell cloning technology. Early MBC responses were mediated by both the classical immunoglobulin $\mathrm{M}\left(\operatorname{IgM}^{+} \mathrm{CD} 27^{+}\right)$and the switched immunoglobulin $\left(\mathrm{swIg}^{+}\right) \mathrm{MBCs}$. The $\mathrm{swIg}^{+} \mathrm{MBC}$ populations and atypical $\mathrm{IgM}^{+}$and $\mathrm{IgD}^{+} \mathrm{MBCs}$ were stable over time. However, the classical $\operatorname{IgM}^{+} \mathrm{CD} 27^{+} \mathrm{MBCs}$ declined quickly. In addition, the NAb response was found to target a fusion loop-proximal antigenic site within the YFV EDII protein ${ }^{60}$.

Vaccination of healthy donors with the live attenuated vaccine YFV 17D triggers the activation of innate and adaptive immune responses. Induction of strong YFV-specific neutralization titers are correlated with soluble IL-6R levels and activation of $\mathrm{CD}^{+} \mathrm{T}$ cell responses during the early stage of vaccination ${ }^{61}$. Immune activation promotes strong NAb titers. However, another study pinpointed that the pre-active environment in vaccinees, such as the presence of proinflammatory monocytes and activation of $\mathrm{CD} 8^{+} \mathrm{T}$ cells and $\mathrm{B}$ cells, contributes to lower neutralization titers and reduction of MBC populations ${ }^{62}$. Furthermore, a study conducted in Brazil suggests that one or more boosters of YFV 17DD following primary vaccination helped to restore the levels of $\mathrm{T}$ and $\mathrm{MBC}$ responses and prevented the progressive decline in NAb titers ${ }^{63}$.

\section{ZIKV}

ZIKV is a re-emerging flavivirus that has caused outbreaks in recent years in the Americas and Caribbean ${ }^{64-66}$. The virus can be transmitted by mosquito bites or by sexual contact ${ }^{67-69}$. In addition, the virus has been associated with severe neurological diseases, such as the autoimmune disorder Guillain-Barré syndrome in adults and congenital Zika syndrome in fetuses and infants ${ }^{70-72}$.

The ZIKV E protein is responsible for viral entry into host cells and represents a major target for NAbs ${ }^{73}$. NAbs targeting the EDIII protein have also been shown to protect mice against lethal ZIKV infection'. One early study of plasma of ZIKV patients from a 2016 outbreak in Singapore suggests that the majority of patients had robust ZIKV-specific humoral responses. Anti-ZIKV IgM was detected as early as 2 days post illness onset and peaked during the 10 to 14 day period post illness onset before decreasing at the 3 month to 1 year recovery phase. Anti-ZIKV IgG peaked during the 10 to 14 day period, persisted at high levels for 5 to 6 months, and was still detectable 1 year post infection ${ }^{3}$.

B cells induced in DENV patients are known to share epitopes between DENV serotypes and other flaviviruses along with epitopes unique to each serotype. A multifunction FluoroSpot assay using fluorescently labeled DENV and ZIKV was utilized to simultaneously detect DENV serotype-specific, ZIKV-specific, DENV serotype cross-reactive, and DENV/ZIKV cross-reactive antibodies secreted by individual MBCs following vaccination or natural infection. Although ZIKV is closely related to DENV, minimal DENV and ZIKV cross-reactive MBCs were detected when samples from ZIKV-immune patients were analyzed ${ }^{40,74}$. Antibodies specific for ZIKV EDI/II were cross-reactive, but not neutralizing DENV, which resulted in lethally enhanced DENV disease in mice, though this has not been observed in humans ${ }^{9,75-77}$. Andrade et al. characterized ZIKV-specific MBCs and serum binding and NAb responses to ZIKV at both 2 weeks and 8 months after infection in 31 pediatric patients with (a) no, (b) one, or (c) more than one related prior DENV infection. They found that ZIKV induced robust type-specific $\mathrm{MBC}$ responses. ZIKV-specific antibodies contributed to antiZIKV serum neutralizing activity during the late convalescent stage. Furthermore, prior immunity to DENV only modestly shaped the breadth and magnitude of the MBC responses ${ }^{74}$. Similar results were confirmed in another study in which 
single B cell cloning and large-scale antibody isolation were used to characterize ZIKV-induced $\mathrm{B}$ cell responses in three DENV-experienced donors ${ }^{78}$.

Several studies have characterized human B cells in ZIKV/DENV immune donors. Robust plasmablast populations were elicited in DENV experienced donors during acute ZIKV infection, whereas the magnitude was reduced in DENV immune donors. The plasmablast response during acute ZIKV infection peaked at day 7 post presentation of symptoms and became undetectable by day $15^{79}$. The plasmablasts from the DENV/ZIKV immune subject were expanded with a high level of somatic hypermutation (SHM) similar to secondary DENV infection, and a similar effect was also observed in MBCs and plasmablasts generated by influenza vaccination ${ }^{80}$. In contrast, the plasmablast in the DENV-naïve/ZIKV-immune subject was characterized by low frequency, limited clonal expansion, and low $\mathrm{SHM}^{78}$. While plasmablast-derived mAbs in DENV exposure donors showed ADE effects, mAbs from ZIKV-infected patients without prior DENV exposure showed less crossreactivity to DENV serotypes ${ }^{81}$. At 5 months post infection, MBCs included a mixture of broadly cross-reactive, poorly neutralizing, and de novo generated antibodies that were ZIKV specific and potently neutralizing ${ }^{78}$. Overall, although prior DENV infection has been associated with ADE following ZIKV infection, the complexity of it suggests that further investigation is needed.

\section{Summary and future perspectives}

Humoral immunity, including MBCs and antibody responses, are important for the control of flaviviral infection and host protection. During primary flaviviral infection, there is a rapid expansion of antibody-secreting plasmablasts and induction of virus-specific MBCs. Upon secondary flavivirus infection, MBCs are mostly characterized as highly cross-reactive and secrete antibodies with higher avidity to genetically related flaviviruses.

Co-circulation and epidemiological overlapping of more than one flavivirus in endemic areas has often resulted in the generation of massive cross-reactive MBCs and antibody responses, which are likely to have a strong impact on the development of an effective vaccine and accurate diagnosis of flavivirus infections. MBCs induced during primary DENV infection are known to share epitopes between DENV serotypes and other flaviviruses along with epitopes unique to each serotype. Plasmablast-derived mAbs in DENV patients are broadly cross-reactive against DENV 1-4 serotypes and contribute to the ADE effects ${ }^{31,82}$. There are minimal DENV and ZIKV cross-reactive MBCs, though the two viruses are closely related. Despite the fact that significant work has been conducted on the understanding of the specificity and cross-reactivity of antibody responses to DENV infection, little is known about the role of MBCs and their derived antibodies in other flavivirus infections. Innate immune signaling pathways and inflammatory cytokines are involved in the regulation of $\mathrm{MBC}$ development. However, the underlying immune mechanisms of $\mathrm{MBC}$ development during flavivirus infection and vaccination remain unclear and will be the focus of future investigation.

\section{Author contributions}

Awadalkareem Adam and Servando Cuellar prepared the original draft. Tian Wang acquired funding and wrote, reviewed, and edited the manuscript.

\section{Acknowledgements}

We thank Dr Linsey Yeager (Research and Product Development Operations, The University of Texas Medical Branch, TX, USA) for assisting in manuscript preparation.
1. King NJC, Getts DR, Getts MT, et al: Immunopathology of flavivirus infections. Immunol Cell Biol. 2007; 85(1): 33-42. PubMed Abstract | Publisher Full Text

2. Simmonds P, Becher P, Bukh J, et al: ICTV Virus Taxonomy Profile: Flaviviridae. J Gen Virol. 2017; 98(1): 2-3.

PubMed Abstract | Publisher Full Text | Free Full Text

3. Acosta EG, Kumar A, Bartenschlager R: Revisiting dengue virus-host cell interaction: New insights into molecular and cellular virology. Adv Virus Res. 2014; 88: 1-109.

PubMed Abstract | Publisher Full Text

4. Daep CA, Muñoz-Jordán JL, Eugenin EA: Flaviviruses, an expanding threat in public health: Focus on dengue, West Nile, and Japanese encephalitis virus. J Neurovirol. 2014; 20(6): 539-60.

PubMed Abstract | Publisher Full Text | Free Full Text

5. Hasan SS, Sevvana M, Kuhn RJ, et al.: Structural biology of Zika virus and other flaviviruses. Nat Struct Mol Biol. 2018; 25(1): 13-20. PubMed Abstract | Publisher Full Text | Faculty Opinions Recommendation
6. Cedillo-Barrón L, García-Cordero J, Bustos-Arriaga J, et al: Antibody response to dengue virus. Microbes Infect. 2014; 16(9): 711-20. PubMed Abstract | Publisher Full Text

7. Stettler K, Beltramello M, Espinosa DA, et al.: Specificity, cross-reactivity, and function of antibodies elicited by Zika virus infection. Science. 2016; 353(6301): 823-6.

PubMed Abstract | Publisher Full Text | Faculty Opinions Recommendation

8. Muller DA, Young PR: The flavivirus NS1 protein: Molecular and structural biology, immunology, role in pathogenesis and application as a diagnostic biomarker. Antiviral Res. 2013; 98(2): 192-208. PubMed Abstract | Publisher Full Text

9. Li L, Lok SM, Yu IM, et al:: The flavivirus precursor membrane-envelope protein complex: Structure and maturation. Science. 2008; 319(5871): 1830-4. PubMed Abstract | Publisher Full Text | Faculty Opinions Recommendation

10. Diamond MS, Shrestha B, Marri A, et al.: $B$ cells and antibody play critical roles in the immediate defense of disseminated infection by West Nile encephalitis 
virus. J Virol. 2003; 77(4): 2578-86.

PubMed Abstract | Publisher Full Text | Free Full Text

11. Scott JM, Lebratti TJ, Richner JM, et al.: Cellular and Humoral Immunity Protect against Vaginal Zika Virus Infection in Mice. J Virol. 2018; 92(7): e00038-18.

PubMed Abstract | Publisher Full Text | Free Full Text | Faculty Opinions Recommendation

12. Hogrefe WR: Biomarkers and assessment of vaccine responses. Biomarkers 2005; 10 Suppl 1: S50-7.

PubMed Abstract | Publisher Full Text

13. Seifert M, Küppers R: Human memory B cells. Leukemia. 2016; 30(12): 2283-92. PubMed Abstract | Publisher Full Text

14. Bohannon $\mathrm{C}$, Powers $\mathrm{R}$, Satyabhama $\mathrm{L}$, et al.: Long-lived antigen-induced IgM plasma cells demonstrate somatic mutations and contribute to long-term protection. Nat Commun. 2016; 7: 11826.

PubMed Abstract | Publisher Full Text | Free Full Text

15. Dörner T, Radbruch A: Antibodies and B cell memory in viral immunity. Immunity. 2007; 27(3): 384-92.

PubMed Abstract | Publisher Full Text

16. Liu YJ, Zhang J, Lane PJ, et al:: Sites of specific B cell activation in primary and secondary responses to $\mathrm{T}$ cell-dependent and $\mathrm{T}$ cell-independent antigens. Eur J Immunol. 1991; 21(12): 2951-62. PubMed Abstract | Publisher Full Tex

17. Smith KG, Hewitson TD Nossal GJ, et al: The phenotype and fate of the antibody-forming cells of the splenic foci. Eur J Immunol. 1996; 26(2): 444-8. PubMed Abstract | Publisher Full Text

18. Yoshida $\mathrm{T}$, Mei H, Dörner $\mathrm{T}$, et al:: Memory B and memory plasma cells. Immunol Rev. 2010; 237(1): 117-39.

PubMed Abstract | Publisher Full Text

19. Bhatt S, Gething PW, Brady OJ, et al:: The global distribution and burden of dengue. Nature. 2013; 496(7446): 504-7.

PubMed Abstract | Publisher Full Text | Free Full Text

20. Weaver SC, Vasilakis N: Molecular evolution of dengue viruses: Contributions of phylogenetics to understanding the history and epidemiology of the preeminent arboviral disease. Infect Genet Evol. 2009; 9(4): 523-40. PubMed Abstract | Publisher Full Text | Free Full Text

21. CMarcial-Juárez E, García-Cordero J, Maqueda-Alfaro RA, et al: Cutaneous Dengue Virus Inoculation Triggers Strong B Cell Reactions but Contrastingly Poor T Cell Responses. Virol Sin. 2020; 35(5): 575-587. PubMed Abstract | Publisher Full Text | Free Full Text | Faculty Opinions Recommendation

22. Zompi S, Santich BH, Beatty PR, et al.: Protection from secondary dengue virus infection in a mouse model reveals the role of serotype cross-reactive and T cells. J Immunol. 2012; 188(1): 404-16.

PubMed Abstract | Publisher Full Text | Free Full Text |

Faculty Opinions Recommendation

23. Castañeda DM, Salgado DM, Narváez CF: B cells naturally induced during dengue virus infection release soluble CD27, the plasma level of which is associated with severe forms of pediatric dengue. Virology. 2016; 497: 136-45. PubMed Abstract | Publisher Full Text

24. Mathew A, West K, Kalayanarooj S, et al.: B-cell responses during primary and secondary dengue virus infections in humans. J Infect Dis. 2011; 204(10): 1514-22.

PubMed Abstract | Publisher Full Text | Free Full Text

25. Waickman AT, Gromowski GD, Rutvisuttinunt W, et al:: Transcriptional and clonal characterization of $B$ cell plasmablast diversity following primary and secondary natural DENV infection. EBioMedicine. 2020; 54: 102733. PubMed Abstract | Publisher Full Text | Free Full Text | Faculty Opinions Recommendation

26. Appanna R, $\mathrm{Kg} \mathrm{S}, \mathrm{Xu} \mathrm{MH}$, et al.: Plasmablasts During Acute Dengue Infection Represent a Small Subset of a Broader Virus-specific Memory B Cell Pool. EBioMedicine. 2016; 12: 178-88.

PubMed Abstract | Publisher Full Text | Free Full Text

27. Andrade P, Narvekar P, Montoya M, et al.: Primary and Secondary Dengue Virus Infections Elicit Similar Memory B-Cell Responses, but Breadth to Othe Serotypes and Cross-Reactivity to Zika Virus Is Higher in Secondary Dengue. $J$ Infect Dis. 2020; 222(4): 590-600.

PubMed Abstract | Publisher Full Text | Free Full Text | Faculty Opinions Recommendation

28. Priyamvada $\mathrm{L}$, Cho A, Onlamoon N, et al:: B Cell Responses during Secondary Dengue Virus Infection Are Dominated by Highly Cross-Reactive, MemoryDerived Plasmablasts. J Virol. 2016; 90(12): 5574-85. PubMed Abstract | Publisher Full Text | Free Full Tex

29. Patel $\mathrm{B}$, Longo $\mathrm{P}$, Miley MJ, et al:: Dissecting the human serum antibody response to secondary dengue virus infections. PLoS Negl Trop Dis. 2017 11(5): e0005554.

PubMed Abstract | Publisher Full Text | Free Full Text

30. Wahala WMPB, de Silva AM: The human antibody response to dengue virus infection. Viruses. 2011; 3(12): 2374-95.

PubMed Abstract | Publisher Full Text | Free Full Text
31. Katzelnick LC, Gresh L, Halloran ME, et al.: Antibody-dependent enhancement of severe dengue disease in humans. Science. 2017; 358(6365): 929-32. PubMed Abstract | Publisher Full Text | Free Full Text

32. Gunisetty S, Nayak K, Rai RC, et al:: Analysis of dengue specific memory $B$ cells, neutralizing antibodies and binding antibodies in healthy adults from India. Int J Infect Dis. 2019; 84S: S57-S63.

PubMed Abstract | Publisher Full Text | Faculty Opinions Recommendation

33. Sánchez-Vargas LA, Kounlavouth S, Smith ML, et al.: Longitudinal Analysis of Memory B and T Cell Responses to Dengue Virus in a 5-Year Prospective Cohort Study in Thailand. Front Immunol. 2019; 10: 1359

PubMed Abstract | Publisher Full Text | Free Full Text |

Faculty Opinions Recommendation

34. Nivarthi UK, Kose N, Sapparapu G, et al:: Mapping the Human Memory B Cell and Serum Neutralizing Antibody Responses to Dengue Virus Serotype 4 Infection and Vaccination. J Virol. 2017; 91(5): e02041-16.

PubMed Abstract | Publisher Full Text | Free Full Text |

Faculty Opinions Recommendation

35. Smith SA, de Alwis AR, Kose N, et al.: Isolation of dengue virus-specific memory $B$ cells with live virus antigen from human subjects following natural infection reveals the presence of diverse novel functional groups of antibody clones. J Virol. 2014; 88(21): 12233-41.

PubMed Abstract | Publisher Full Text

36. Cox KS, Tang A, Chen Z, et al:: Rapid isolation of dengue-neutralizing antibodies from single cell-sorted human antigen-specific memory B-cell cultures. mAbs. 2016; 8(1): 129-40.

PubMed Abstract | Publisher Full Text | Free Full Text

37. Young E, Carnahan RH, Andrade DV, et al:: Identification of Dengue Virus Serotype 3 Specific Antigenic Sites Targeted by Neutralizing Human Antibodies. Cell Host Microbe. 2020; 27: 710-724.e7.

PubMed Abstract | Publisher Full Text | Free Full Text

Faculty Opinions Recommendation

38. Woda M, Mathew A: Fluorescently labeled dengue viruses as probes to identify antigen-specific memory B cells by multiparametric flow cytometry. $J$ Immunol Methods. 2015; 416: 167-77.

PubMed Abstract | Publisher Full Text | Free Full Text

39. Hadjilaou A, Green AM, Coloma J, et al:: Single-Cell Analysis of B Cell/Antibody Cross-Reactivity Using a Novel Multicolor FluoroSpot Assay. J Immunol. 2015; 195(7): 3490-6.

PubMed Abstract | Publisher Full Text

40. Adam A, Woda M, Kounlavouth S, et al:: Multiplexed FluoroSpot for the Analysis of Dengue Virus- and Zika Virus-Specific and Cross-Reactive Memory B Cells. $J$ Immunol. 2018; 201(12): 3804-14.

PubMed Abstract | Publisher Full Text | Free Full Text

41. Durham ND, Agrawal A, Waltari E, et al.: Broadly neutralizing human antibodies against dengue virus identified by single $B$ cell transcriptomics. elife. 2019; 8: e52384.

PubMed Abstract | Publisher Full Text | Free Full Text |

Faculty Opinions Recommendation

42. Petersen LR, Brault AC, Nasci RS: West Nile virus: Review of the literature. JAMA. 2013; 310(3): 308-15.

PubMed Abstract | Publisher Full Text | Free Full Text

43. Carson PJ, Konewko P, Wold KS, et al.: Long-term clinical and neuropsychological outcomes of West Nile virus infection. Clin Infect Dis. 2006; 43(6): 723-30

PubMed Abstract | Publisher Full Text | Faculty Opinions Recommendation

44. Ou AC, Ratard RC: One-year sequelae in patients with West Nile Virus encephalitis and meningitis in Louisiana. J La State Med Soc. 2005; 157(1): 42-6.

PubMed Abstract

45. Cook RL, Xu X, Yablonsky EJ, et al.: Demographic and clinical factors associated with persistent symptoms after West Nile virus infection. Am J Trop Med Hyg. 2010; 83(5): 1133-6.

PubMed Abstract | Publisher Full Text | Free Full Text

46. Sadek JR, Pergam SA, Harrington JA, et al.: Persistent neuropsychological impairment associated with West Nile virus infection. J Clin Exp Neuropsychol. 2010; 32(1): 81-7.

PubMed Abstract | Publisher Full Text | Faculty Opinions Recommendation

47. Nolan MS, Podoll AS, Hause AM, et al:: Prevalence of chronic kidney disease and progression of disease over time among patients enrolled in the Houston West Nile virus cohort. PLoS One. 2012; 7(7): e40374. PubMed Abstract | Publisher Full Text | Free Full Text

48. Patel H, Sander B, Nelder MP: Long-term sequelae of West Nile virus-related illness: A systematic review. Lancet Infect Dis. 2015; 15(8): 951-9. PubMed Abstract | Publisher Full Text

49. Sejvar JJ: Clinical manifestations and outcomes of West Nile virus infection. Viruses. 2014; 6(2): 606-23.

PubMed Abstract | Publisher Full Text | Free Full Text

50. Weatherhead JE, Miller VE, Garcia MN, et al:: Long-term neurological outcomes in West Nile virus-infected patients: An observational study. Am J Trop Med 
Hyg. 2015; 92(5): 1006-12.

PubMed Abstract | Publisher Full Text | Free Full Text

51. Anastasiadou A, Kakoulidis I, Butel D, et al:: Follow-up study of Greek patients with West Nile virus neuroinvasive disease. Int $J$ Infect Dis. 2013; 17(7): e494-7. PubMed Abstract | Publisher Full Text

52. C Giordano D, Draves KE, Young LB, et al:: Protection of mice deficient in mature $B$ cells from West Nile virus infection by passive and active immunization. PLoS Pathog. 2017; 13(11): e1006743. PubMed Abstract | Publisher Full Text | Free Full Text | Faculty Opinions Recommendation

53. Tsioris K, Gupta NT, Ogunniyi AO, et al.: Neutralizing antibodies against West Nile virus identified directly from human $B$ cells by single-cell analysis and next generation sequencing. Integr Biol (Camb). 2015; 7(12): 1587-97. PubMed Abstract | Publisher Full Text | Free Full Text

54. Petrovsky N, Larena M, Siddharthan V, et al:: An inactivated cell culture Japanese encephalitis vaccine (JE-ADVAX) formulated with delta inulin adjuvant provides robust heterologous protection against West Nile encephalitis via cross-protective memory $B$ cells and neutralizing antibody. J Virol. 2013; 87(18): 10324-33. PubMed Abstract | Publisher Full Text | Free Full Text

55. Purtha WE, Tedder TF, Johnson S, et al:: Memory B cells, but not long-lived plasma cells, possess antigen specificities for viral escape mutants. $J$ Exp Med. 2011; 208(13): 2599-606

PubMed Abstract | Publisher Full Text | Free Full Text |

Faculty Opinions Recommendation

56. Xia J, Winkelmann ER, Gorder SR, et al.: TLR3- and MyD88-dependent signaling differentially influences the development of West Nile virus-specific B cell responses in mice following immunization with RepliVAX WN, a single-cycle flavivirus vaccine candidate. J Virol. 2013; 87(22): 12090-101. PubMed Abstract | Publisher Full Text | Free Full Text

57. Waggoner JJ, Rojas A, Pinsky BA: Yellow Fever Virus: Diagnostics for a Persistent Arboviral Threat. J Clin Microbiol. 2018; 56(10): e00827-18. PubMed Abstract | Publisher Full Text | Free Full Text | Faculty Opinions Recommendation

58. Barrett ADT: Yellow Fever in Angola and Beyond--The Problem of Vaccine Supply and Demand. N Engl J Med. 2016; 375(4): 301-3. PubMed Abstract | Publisher Full Text

59. Watson AM, Lam LKM, Klimstra WB, et al.: The 17D-204 Vaccine Strain-Induced Protection against Virulent Yellow Fever Virus Is Mediated by Humoral Immunity and CD4+ but not CD8+ T Cells. PLoS Pathog. 2016; 12(7): e1005786. PubMed Abstract | Publisher Full Text | Free Full Text

60. W Wec AZ, Haslwanter D, Abdiche YN, et al:: Longitudinal dynamics of the human B cell response to the yellow fever 17D vaccine. Proc Natl Acad Sci U S A. 2020; 117(12): 6675-85.

PubMed Abstract | Publisher Full Text | Free Full Text | Faculty Opinions Recommendation

61. Kohler S, Bethke N, Böthe M, et al.: The early cellular signatures of protective immunity induced by live viral vaccination. Eur J Immunol. 2012; 42(9): 2363-73.

PubMed Abstract | Publisher Full Text

62. Muyanja E, Ssemaganda A, Ngauv $P$, et al.: Immune activation alters cellular and humoral responses to yellow fever 17D vaccine. J Clin Invest. 2014; 124(7): 3147-58.

PubMed Abstract | Publisher Full Text | Free Full Text

63. Campi-Azevedo AC, Peruhype-Magalhāes V, Coelho-Dos-Reis JG, et al:: 17DD Yellow Fever Revaccination and Heightened Long-Term Immunity in Populations of Disease-Endemic Areas, Brazil. Emerg Infect Dis. 2019; 25(8): 1511-21.

PubMed Abstract | Publisher Full Text | Free Full Text |

Faculty Opinions Recommendation

64. Zika virus: A new global threat for 2016. Lancet. 2016; 387(10014): 96 PubMed Abstract | Publisher Full Text

65. Chen LH, Hamer DH: Zika Virus: Rapid Spread in the Western Hemisphere. Ann Intern Med. 2016; 164(9): 613-5. PubMed Abstract | Publisher Full Text

66. Samarasekera $\mathrm{U}$, Triunfol M: Concern over Zika virus grips the world. Lancet 2016; 387(10018): 521-4

PubMed Abstract | Publisher Full Text

67. Musso D: Zika Virus Transmission from French Polynesia to Brazil. Emerg Infect Dis. 2015; 21(10): 1887.

PubMed Abstract | Publisher Full Text | Free Full Text
68. Oliveira Melo AS, Malinger G, Ximenes R, et al:: Zika virus intrauterine infection causes fetal brain abnormality and microcephaly: Tip of the iceberg? Ultrasound Obstet Gynecol. 2016; 47(1): 6-7. PubMed Abstract | Publisher Full Text

69. Cao-Lormeau VM, Blake A, Mons S, et al: Guillain-Barré Syndrome outbreak associated with Zika virus infection in French Polynesia: A case-control study. associated with Zika virus infection

Lancet. 2016; 387(10027): 1531-9.
PubMed Abstract | Publisher Full Text | Free Full Text |

Faculty Opinions Recommendation

70. Kleber de Oliveira W, Cortez-Escalante J, de Oliveira WTGH, et al: Increase in Reported Prevalence of Microcephaly in Infants Born to Women Living in Areas with Confirmed Zika Virus Transmission During the First Trimester of Pregnancy - Brazil, 2015. MMWR Morb Mortal Wkly Rep. 2016; 65(9): 242-7. PubMed Abstract | Publisher Full Text

71. Rasmussen SA, Jamieson DJ, Honein MA, et al:: Zika Virus and Birth Defects--Reviewing the Evidence for Causality. N Engl J Med. 2016; 374(20) $1981-7$.

PubMed Abstract | Publisher Full Text

72. Koppolu V, Shantha Raju T: Zika virus outbreak: A review of neurological complications, diagnosis, and treatment options. J Neurovirol. 2018; 24(3): 255-72.

PubMed Abstract | Publisher Full Text | Faculty Opinions Recommendation

73. Collins MH, Tu HA, Gimblet-Ochieng C, et al:: Human antibody response to Zika targets type-specific quaternary structure epitopes. JCI Insight. 2019; 4(8): e124588.

PubMed Abstract | Publisher Full Text | Free Full Text |

Faculty Opinions Recommendation

74. Andrade P, Gimblet-Ochieng C, Modirian F, et al:: Impact of pre-existing dengue immunity on human antibody and memory $B$ cell responses to Zika. dengue immu

PubMed Abstract | Publisher Full Text | Free Full Text | Faculty Opinions Recommendation

75. Langerak T, Mumtaz N, Tolk VI, et al.: The possible role of cross-reactive dengue virus antibodies in Zika virus pathogenesis. PLoS Pathog. 2019; 15(4): e1007640.

PubMed Abstract | Publisher Full Text | Free Full Text |

Faculty Opinions Recommendation

76. Castanha PMS, Souza WV, Braga C, et al:: Perinatal analyses of Zika- and dengue virus-specific neutralizing antibodies: A microcephaly case-control study in an area of high dengue endemicity in Brazil. PLoS Negl Trop Dis. 2019; 13(3): e0007246.

PubMed Abstract | Publisher Full Text | Free Full Text |

Faculty Opinions Recommendation

77. Salazar V, Jagger BW, Mongkolsapaya J, et al.: Dengue and Zika Virus Cross-Reactive Human Monoclonal Antibodies Protect against Spondweni Virus Infection and Pathogenesis in Mice. Cell Rep. 2019; 26(6): 1585-1597.e4. PubMed Abstract | Publisher Full Text | Free Full Text

Faculty Opinions Recommendation

78. Rogers TF, Goodwin EC, Briney B, et al.: Zika virus activates de novo and crossreactive memory $\mathrm{B}$ cell responses in dengue-experienced donors. Sci Immunol. 2017; 2(14): eaan6809.

PubMed Abstract | Publisher Full Text | Free Full Text

79. Ricciardi MJ, Magnani DM, Grifoni A, et al:: Ontogeny of the B- and T-cell response in a primary Zika virus infection of a dengue-naïve individual during the 2016 outbreak in Miami, FL. PLoS Negl Trop Dis. 2017; 11(12): e0006000. PubMed Abstract | Publisher Full Text | Free Full Text

80. Wrammert J, Smith K, Miller J, et al.: Rapid cloning of high-affinity human monoclonal antibodies against influenza virus. Nature. 2008; 453(7195): $667-71$.

PubMed Abstract | Publisher Full Text | Free Full Text

81. Chaumik SK, Priyamvada L, Kauffman RC, et al.: Pre-Existing Dengue Immunity Drives a DENV-Biased Plasmablast Response in ZIKV-Infected Patient Viruses. 2018; 11(1): 19

PubMed Abstract | Publisher Full Text | Free Full Text | Faculty Opinions Recommendation

82. Martín-Acebes MA, Saiz JC, Jiménez de Oya N: Antibody-Dependent Enhancement and Zika: Real Threat or Phantom Menace? Front Cell Infect Microbiol. 2018; 8: 44

PubMed Abstract | Publisher Full Text | Free Full Text |

Faculty Opinions Recommendation 